\title{
A new Lepraria from Brazil
}

\author{
John A. Elix ${ }^{1,4}$, Adriano A. Spielmann ${ }^{2}$ and Dag O. Øvstedal ${ }^{3}$
}

Received: 06.11.2009; accepted: 30.12.2009

\begin{abstract}
A new Lepraria from Brazil). Lepraria brasiliensis is described from Minas Gerais, Brazil. It is mainly characterized by the presence of thamnolic acid and atranorin as chemical constituents.

Key words: atranorin, Brazil, Lepraria brasiliensis, thamnolic acid

RESUMO - (Uma nova Lepraria do Brasil). Lepraria brasiliensis é uma espécie nova encontrada em Minas Gerais, Brasil, caracterizada pela presença de ácido taminólico e atranorina como constituintes químicos principais.

Palavras-chave: atranorina, ácido taminólico, Brasil, Lepraria brasiliensis
\end{abstract}

\section{Introduction}

In a recent review of the lichen genus Lepraria in South America (Flakus \& Kukwa 2007), 19 species were recorded for the continent but none are known to contain thamnolic acid. Here we report Lepraria brasiliensis, a new South American Lepraria which contains thamnolic acid and atranorin.

\section{Material and methods}

The material studied is deposited in SP and BG. The morphology was examined using a Zeiss Stemi 2000C stereo microscope, and a Zeiss Axiolab compound microscope. Chemical constituents were identified by thin layer chromatography (Elix \& Ernst-Russell 1993) and high performance liquid chromatography (Elix et al. 2003).

\section{Results}

Lepraria brasiliensis Elix, Spielmann \& Øvstedal, sp. nov.

Figures 1-2

Thallus leprosus, non stratosus, granulis 2028 m diam., albus vel virido-cinereus, ad margines non lobatus; atranorinam, acidum thamnolicum, acidum decarboxythamnolicum, et acidum incognitum continens.

Type: BRAZIL. Minas Gerais: Catas altas, Parque Natural do Caraça, trilha entre a Ponte do Bode e o campo de futebol, $2006^{\prime} 06.0^{\prime \prime} \mathrm{S}, 4329^{\prime} 12.9^{\prime \prime} \mathrm{W}$, A.A. Spielmann, L. S. Canez \& M. P. Marcelli, $2345-$ IV - 2006, alt. 1265 m, em tronco de Eucalyptus, mata aberta (holotypus SP, isotypus BG

Thallus grey-green, leprose, up to $10 \mathrm{~cm}$ wide, thin, with a somewhat uneven distribution of soredia, in some parts with a thin white hypothallus. Margin diffuse, lobes, sublobes and medulla absent. Soredia relatively fine, 20-28 $\mu \mathrm{m}$ diam., \pm roundish, forming an uneven continuous layer, consoredia absent, with a few projecting hyphae. Hyphae smooth, 0.7-0.9 $\mu \mathrm{m}$ thick. Photobiont a unicellular green alga, algal cells 10-12 $\mu \mathrm{m}$ wide.

Chemistry: thallus $\mathrm{K}+$ bright yellow, $\mathrm{C}-, \mathrm{KC}-$, $\mathrm{P}+$ yellow-orange; thamnolic acid (major), decarboxythamnolic acid (minor), atranorin (minor), unknown (trace); fatty acids absent.

Habitat: Lepraria brasiliensis was found growing on a Eucalyptus trunk, in a humid location with diffuse light near a stream (Figure 2). Eucalyptus is an

1. Australian National University, Department of Chemistry, Canberra, ACT 0200, Australia

2. Instituto de Botânica, Seção de Micologia e Liquenologia, Av. Miguel Stéfano, 3687, Água Funda, São Paulo - SP, 04301-902, Brazil

3. Bergen Museum, DNS, Allégt. 41, N-5007 Bergen, Norway

4. Corresponding author: adrianospielmann@yahoo.com.br 


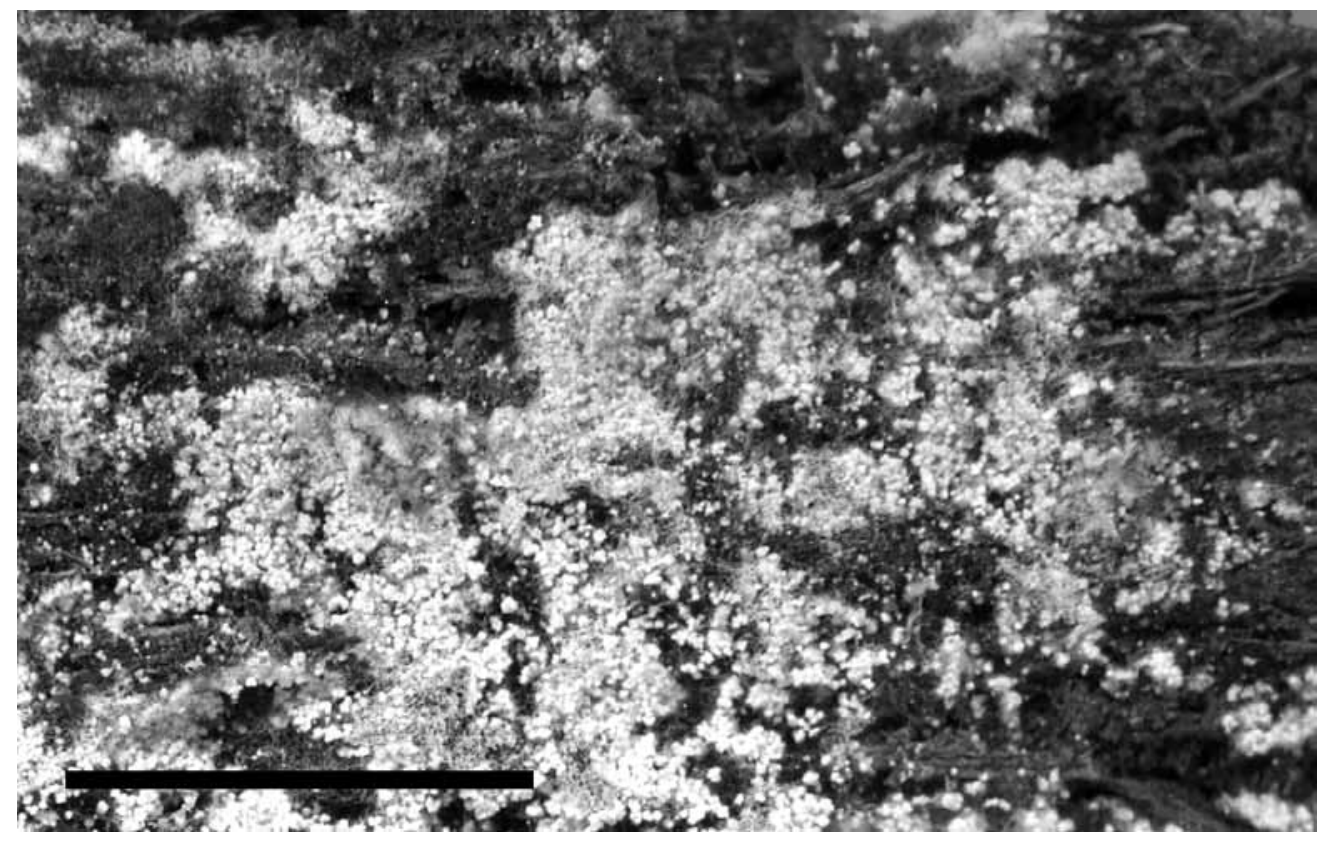

Figure 1. Lepraria brasiliensis. Holotype. Scale bar $=5 \mathrm{~mm}$.

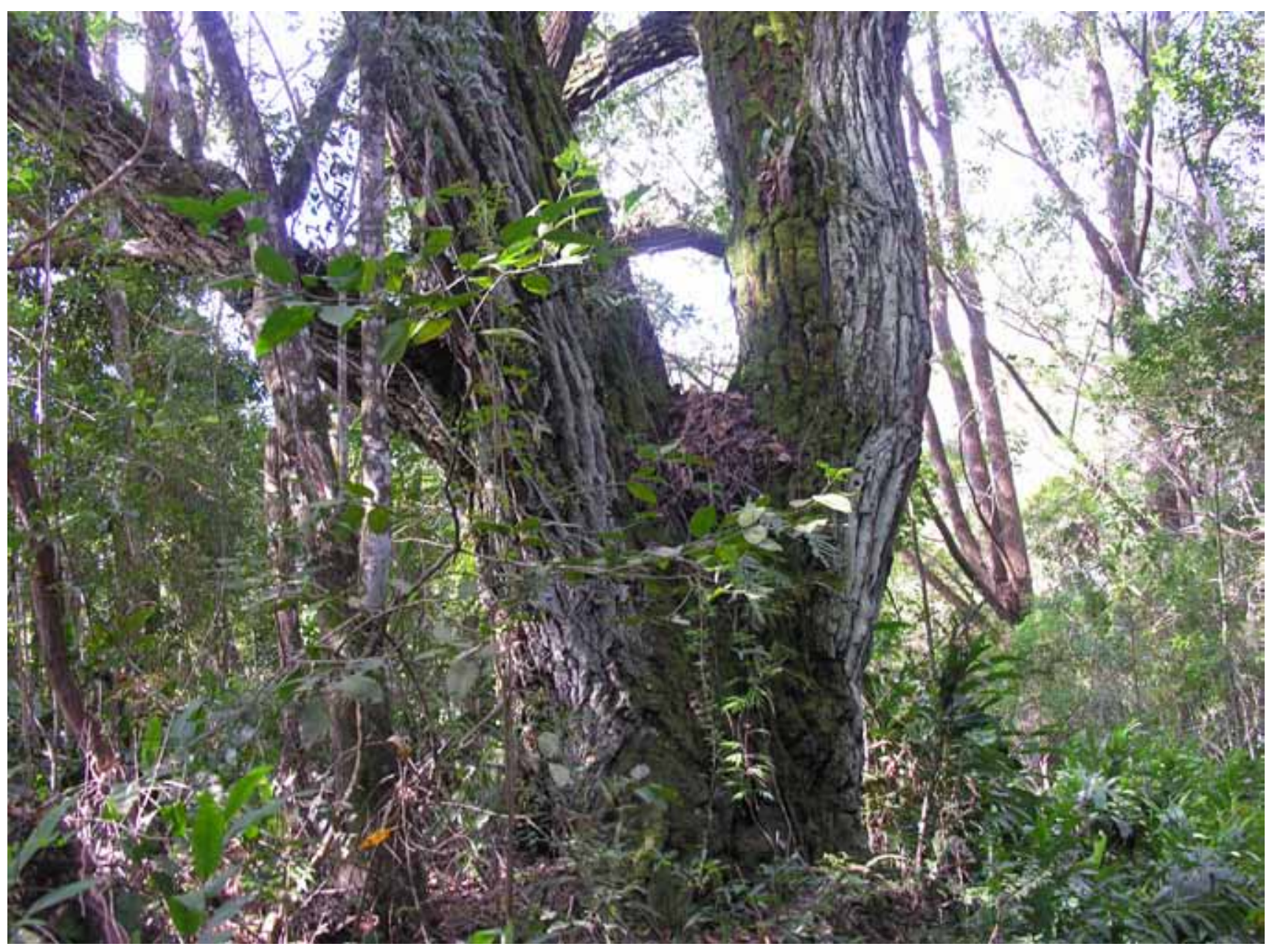

Figure 2. Lepraria brasiliensis (gray patches on the trunk) on type locality. 
introduced genus, but the general ecology is typical for Brazilian, montane riparian forests.

\section{Discussion}

This new species resembles both Lepraria umbricola Tønsberg and L. nylanderiana Kummerl. \& Leuckert, as these species typically have thin, grey-green thalli with fine soredia (20-30 $\mu \mathrm{m}$ diam.) and contain thamnolic acid. In well developed specimens $L$. nylanderiana is reported to have sublobes and a conspicuous greyish hypothallus (Leuckert et al. 1995), but these characters were not evident in the specimens that we have examined (material from SW Europe, determined by T. Tønsberg). Lepraria umbricola on the other hand, usually has a thicker thallus and a tendency to become ochre-coloured in the herbarium, but these are not reliable characters (material from northern Europe in BG and determined by T. Tønsberg). The only reliable character appears to be the chemistry, with L. umbricola containing thamnolic acid and decarboxythamnolic acid (trace), and $L$. nylanderiana containing thamnolic acid, roccellic acid, decarboxythamnolic acid (trace) and atranorin ( \pm trace). Lepraria brasiliensis contains thamnolic acid (major), decarboxythamnolic acid (minor), atranorin (minor) and traces of an unknown compound.

Two other recently described species of Lepraria from Thailand also contain thamnolic acid, viz. $L$. aurescens Orange \& Wolseley and $L$. pulchra Orange \& Wolseley (Orange \& Wolseley 2005). Both of these species lack atranorin, and in addition $L$. pulchra has a medulla and lobes, while L. aurescens has larger soredia $(40-100 \mu \mathrm{m})$ and a prominent brown hypothallus.

It is interesting to find a new species in a wellstudied locality like Caraça, as Vainio (1890a,b) thoroughly investigated this region for his doctoral thesis, and during a recent meeting of the "Grupo Latino Americano de Liquenólogos" (GLAL-3) lichens were recollected in this area (Marcelli \& Seaward 1998). This no doubt reflects the high lichen diversity in this region of Brazil.

\section{Acknowledgements}

We are indebted to Dr. T. Tønsberg, Bergen, for access to material of Lepraria nylanderiana, and to Mr. J. Berge and Mrs. B. Helle (Bergen), for assistance with photography. We also thank Dr. Marcelo Pinto Marcelli (São Paulo) for the opportunity to collect at Caraça, and Father Lauro Palú, C.M., for revisiting Caraça to take the habitat photographs.

\section{Literature cited}

Elix, J.A. \& Ernst-Russell, K.D. 1993. A Catalogue of Standardized Thin Layer Chromatographic Data and Biosynthetic relationships for Lichen Substances. 2 ed. Australian National University, Canberra.

Elix, J.A., Giralt, M. \& Wardlaw, J.H. 2003. New chloro-depsides from the lichen Dimelaena radiata. Bibliotheca Lichenologica 86: 1-7.

Flakus, A. \& Kukwa, M. 2007. New species and records of Lepraria (Stereocaulaceae, lichenized Ascomycota) from South America. The Lichenologist 39: 463-474.

Leuckert, Ch., Kümmerling, H. \& Wirth, V. 1995. Chemotaxonomy of Lepraria Ach. and Leproloma Nyl. ex Crombie, with particular reference to Central Europe. Bibliotheca Lichenologica 58: 245-259.

Marcelli, M.P. \& Seaward, M.R.D. (eds.) 1998. Lichenology in Latin America: history, current knowledge and applications. CETESB, São Paulo.

Orange, A. \& Wolseley, P. 2005. Two new thamnolic acid-containing Lepraria species from Thailand. Lichenologist 37: 247-250.

Tønsberg, T. 1992. The sorediate and isidiate, corticolous, crustose lichens in Norway. Sommerfeltia 14: 1-331.

Vainio, E.A. 1890a. Étude sur la classification naturelle et la morphologie des Lichens du Brésil. Pars prima. Acta Societatis pro Fauna et Flora Fennica 7: I-XXIX, 1-247.

Vainio, E.A. 1890b. Étude sur la classification naturelle et la morphologie des Lichens du Brésil. Pars secunda. Acta Societatis pro Fauna et Flora Fennica 7: 1-256. 